\title{
Development and Evaluation of a Blog about Cleft Lip and Cleft Palate and Hearing
}

\author{
${ }^{1}$ Hospital for Rehabilitation of Craniofacial Anomalies, Universidade \\ de São Paulo, Bauru, SP, Brazil \\ 2 Department of Speech-Language Pathology and Audiology, Bauru School \\ of Dentistry, Universidade de São Paulo (FOB-USP), Bauru, SP, Brazil \\ ${ }^{3}$ Centro de Reabilitação Lucy Montoro, Faculdade de Medicina de \\ Marília - FAMEMA, Marília, SP, Brazil \\ ${ }^{4}$ Department of Ophthalmology, Otolaryngology and Head and Neck \\ Surgery, Botucatu Medical School, Universidade Estadual Paulista \\ (FMB-UNESP), Botucatu, SP, Brazil
}

Luciana Paula Maximino ${ }^{1,2}$ Ticiana Cristina de Freitas Zambonato ${ }^{1}$ Mirela Machado Picolini-Pereira ${ }^{3}$ Camila de Castro Corrêa ${ }^{4}$ Mariza Ribeiro Feniman ${ }^{1,2}$ Wanderléia Quinhoneiro Blasca ${ }^{2}$

Address for correspondence Luciana Paula Maximino, PhD, Department of Speech-Language Pathology and Audiology, Faculdade de Odontologia de Bauru, Universidade de São Paulo (FOB-USP), AI. Dr. Octávio Pinheiro Brisola, 9-75, Vila Universitária, 17012-900 - Bauru, SP - Brasil - Caixa-Postal: 73 (e-mail: lumaximino@uol.com.br).

Int Arch Otorhinolaryngol 2018;22:60-67.

\begin{abstract}
Introduction Cleft lip and cleft palate can result in impairments in communication, specifically in hearing, making the use of technological resources such as blogs a fundamental guideline for health professionals.

Objective The aim of this study was to prepare and analyze the access to a blog about cleft lip and cleft palate and hearing as a pedagogical tool for health professionals.

Methods The first stage for the development of the blog was the selection of the content that would be addressed and the respective illustrations. The second stage was making the blog available through the WordPress platform, and the third stage included the evaluation of the blog, of the access to the WordPress statistical features, and of the quality of the blog through the Emory questionnaire, which was answered by 75 professionals.

Results The blog, titled "Fissure and Hearing", was developed with the architecture of a digital information environment containing a system of organization, navigation,

Keywords

- cleft lip

- cleft palate

- hearing loss

- health education

- education

- distance labeling and search (first stage). The address hosting the blog was: http://fissuraeaudicao.wordpress.com (second stage). The result of the third stage included 56,269 views of the blog from different countries, and Brazil was the country with the highest viewing. Regarding the assessment by the Emory questionnaire, we found that for most of the major issues, the percentages obtained were or equal to $90 \%$, while the analysis of the scales, navigation and structure presented the lowest scores.

Conclusion The blog was developed and enabled greater access to information available on the web about cleft lip and cleft palate and hearing.
\end{abstract}

\section{Introduction}

In the context of craniofacial anomalies, cleft lip and cleft palate affect one person in every 500 to 700 births, which means the birth of a carrier of a malformation that involves the lip structures and the palate every 2.5 minutes in the world. ${ }^{1,2}$

received

August 16, 2016

accepted

March 21, 2017

published online

May 31, 2017

10.1055/s-0037-1603494. ISSN $1809-9777$.
The possible impairments related to cleft lip and cleft palate affect different aspects of life, such as feeding, ${ }^{3}$ dental, cosmetic, ${ }^{4}$ socioeconomic, family, educational and social aspects. ${ }^{5}$

The implications for oral communication due to phonoarticulatory, linguistic ${ }^{6}$ and audiological ${ }^{7-10}$ changes are also emphasized. Regarding the audiological changes, there is

Copyright @ 2018 by Thieme Revinter

Publicações Ltda, Rio de Janeiro, Brazil

License terms

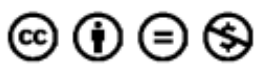


dysfunction in the Eustachian tube, presence of otitis media, conductive and bilateral hearing loss, ${ }^{11-13}$ as well as changes in auditory processing. ${ }^{7-10}$

These findings indicate the need for a follow-up of the hearing and middle ear conditions in individuals with cleft lip and cleft palate, allowing for an early established and assertive intervention. ${ }^{11,14}$

As a facilitator in the process, there is the dissemination of knowledge to professionals working in the field, assisting in the planning of the treatment for this population. One of the means that allows the transmission of information is the use of information and communication technologies (ICTs), reducing communication issues related to geographical distances, reducing costs, and optimizing time. ${ }^{15}$

The ICTs can be used to access many different things, such as health websites, information and interactive electronic health records, health programs to support decision-making, second formative opinions, interactions between specialized centers, education programs adapted for health to increase public access to this information, and they can improve the quality of care, reduce pipeline errors, increase collaboration and encourage the adoption of healthy habits. ${ }^{16-19}$ But, in order to achieve this, it is necessary that the information is easily accessible, attractive and reliable for the guidance and promotion of health in various areas. ${ }^{19} \mathrm{~A}$ review process of the development of these tools to measure their quality, ${ }^{20}$ using the Emory questionnaire, for example, is also necessary. ${ }^{21,22}$

Publications on tele-audiology have focused more in the assessment or intervention, verifying that studies have been intensifying, especially in the last five years. ${ }^{23}$ However, studies observed in the field of fissures, hearing and guidance to health professionals have not been conducted, only guidelines for the population have been offered so far. ${ }^{24}$ Therefore, the aim of the present study was to develop and analyze the access to a blog about cleft lip and hearing as a pedagogical tool for health professionals, with the use of interactive tele-education.

\section{Methods}

The present work was developed and implemented after approval by the Research Ethics Committee of the institution concerned, under protocol number 376/2008.

For the transmission of information on the relationship of cleft lip and cleft palate and the auditory system, the means of transmission of the available information were analyzed, and the web-based virtual environment, the blog, was chosen for the development of the present study.

It is known that hearing health has fundamental importance to the interpersonal communication processes, and it affects the individuals' quality of life and self-esteem. Considering the possible prevention aspects and hearing health optimization, we chose the theme "auditory system and cleft lip and cleft palate."

This tool was designed for health professionals, among them physicians, otolaryngologists, audiologists, psychologists, surgeons, dentists and other professionals who work with individuals with cleft lip and cleft palate.

\section{$1^{\text {st }}$ Stage - Development of the Blog}

The development of the blog followed the instructional and contextualized design model proposed by Filatro and Pico$n e z^{25}$, in which the analyses stages, design, development, implementation and evaluation are produced together without distinction of stages, making it possible to make changes throughout the process.

An educational theoretical script was initially developed using the following sources of information: books, national and international journal articles, information available on the web (educational institution sites and dissertations from these institutions available on line). The information collected was simplified regarding the quantity and complexity, so that the reading was established in a more continuous and stimulating way. The links, images and videos that were selected were consistent with the theoretical content, creating the most visually attractive materials, thus consolidating learning. Finally, the theoretical educational content was divided into didactic topics ( - Table 1 ).

The blog was developed using the WordPress platform, available for free on the internet at the internet address www. wordpress.com, which is easy to use and understand for both the creator and the user. In the present study, the free option of the service was used, but there is the option of paid upgrades.

During the development of the blog, the principles of objectivity, content visibility and ease of navigation were followed in order to design the environment according to its target audience.

In addition, the systems used to optimize the operation of a digital information environment are: organization system, navigation system, labeling system and search system. ${ }^{26}$

\section{$2^{\text {nd }}$ Stage - Making the Blog Available}

The WordPress platform was used to make the blog available, and we needed to create an account on the platform with a

Table 1 Educational and theoretical blog content

\begin{tabular}{|c|c|}
\hline \multirow{3}{*}{$\begin{array}{l}\text { Cleft lip and } \\
\text { cleft palate }\end{array}$} & Incidence \\
\hline & Etiology \\
\hline & Cleft types \\
\hline Hearing & Hearing disability \\
\hline \multirow{3}{*}{$\begin{array}{l}\text { Adaptation of the } \\
\text { hearing aid }\end{array}$} & Selection of the hearing aid \\
\hline & Verification of the hearing aid \\
\hline & Validation of the hearing aid \\
\hline \multirow{4}{*}{$\begin{array}{l}\text { Cleft lip and cleft } \\
\text { palate and } \\
\text { hearing disability }\end{array}$} & Function of the Eustachian tube \\
\hline & Otitis media \\
\hline & $\begin{array}{l}\text { Etiology of middle ear alteration } \\
\text { in individuals with cleft lip } \\
\text { and cleft palate }\end{array}$ \\
\hline & $\begin{array}{l}\text { Influence of otitis in language } \\
\text { development }\end{array}$ \\
\hline \multirow{2}{*}{$\begin{array}{l}\text { Treatment for } \\
\text { otitis media }\end{array}$} & Surgical intervention \\
\hline & $\begin{array}{l}\text { Systematic monitoring and } \\
\text { adaptation of the hearing aid }\end{array}$ \\
\hline
\end{tabular}


user name, password and e-mail, and then build the pages with the desired information by following the instructions on the website.

\section{$3^{\text {rd }}$ Stage - Evaluation of the Blog}

The WordPress platform offers the statistics feature, which allows the creator to check the blog access data in any given period. Thus, we took into consideration the number of accesses between August and October 2015. This was a general analysis of blog to verify the number and origin of the accesses.

The search terms were also observed, that is, the words searched within the blog are also described in the WordPress statistics, presenting the terms and respective quantity of use.

For a subjective evaluation of the blog quality, we asked for the participation of professionals who work at the institution where this research was conducted. We invited specialists in the area of cleft lip and cleft palate, and/or hearing impairment (area of speech therapy, otolaryngology). In addition to non-professional experts who work in the care of individuals with cleft lip and/or hearing impairment (in the fields of social services, psychology, nutrition, nursing and physiotherapy), and professionals working in the field of information technology and communication, we have totalized 75 professionals (-Table 2 ).

These professionals answered the Emory questionnaire, which consists of 36 questions divided into 8 scales that assess content, accuracy, authorship, updates, public, navigation, links and structure, resulting in a score. ${ }^{21,22}$ Three response alternatives were made available for each question, and "agree" corresponded to two points, "disagree" corresponded to one point, and "not applicable" corresponded to zero points. For the analysis, the overall score was obtained,

Table 2 Distribution of the participants, according to the professional qualification $(n=75)$

\begin{tabular}{|l|l|}
\hline Professional qualification & $\begin{array}{l}\text { Number of } \\
\text { participants }\end{array}$ \\
\hline Speech therapy & $53(70.7 \%)$ \\
\hline Social service & $5(6.7 \%)$ \\
\hline Psychology & $4(5.3 \%)$ \\
\hline Nursing & $2(2.7 \%)$ \\
\hline Physiotherapy & $2(2.7 \%)$ \\
\hline Art education & $1(1.3 \%)$ \\
\hline Graphic design & $1(1.3 \%)$ \\
\hline Speech Therapy and Education & $1(1.3 \%)$ \\
\hline Speech Therapy and Nursing Technician & $1(1.3 \%)$ \\
\hline Social Communication - Journalism & $1(1.3 \%)$ \\
\hline Medicine & $1(1.3 \%)$ \\
\hline Nutrition & $1(1.3 \%)$ \\
\hline Dentistry & $1(1.3 \%)$ \\
\hline Nursing technician & $1(1.3 \%)$ \\
\hline TOTAL & $75(100 \%)$ \\
\hline
\end{tabular}

which corresponded to the blog quality as demonstrated in the following formula:

Total score obtained/Possible total score $\times 100=$ Percentage of total possible points $\times 100=$ Percentage of total possible points

Thus, it was possible to relate the percentage obtained with the level of quality of the blog: excellent, $\geq 90 \%$; adequate, from 75 to $89 \%$; poor, $>75 \%^{21,22}$

For the specific analysis of the blog aspects, considering the eight scales, the questions (Qs) were grouped as follows: Q1 to Q6 evaluate the content; Q7 to Q9, the accuracy; Q10 to Q12, the authorship; Q13 and Q14, the updates; Q15 to Q18, the public; Q19 to Q24, the navigation; Q25 to Q30, the external links; and Q31 to Q36 evaluate the structure. ${ }^{21,22}$

\section{Results}

\section{$1^{\text {st }}$ Stage - Development of the Blog}

The structuring of the topic contents was performed, as seen in Table 1.

The optimization of the operation systems of an information environment was performed, allowing for the identification of these systems in the "Fissure and Hearing" blog.

-Fig. 1 illustrates some internal pages of the blog with hypertexts, images and videos. The blog was developed for health professionals. Thus, it features the option of using technical-scientific language in the educational theoretical content.

\section{$2^{\text {nd }}$ Stage - Making the Blog Available}

The address hosting the "Fissure and Hearing" blog was: http://fissuraeaudicao.wordpress.com

\section{$3^{\text {rd }}$ Stage - Evaluation of the Blog}

During the stipulated period, 56,269 visits to the "Fissure and Hearing" blog were verified. According to the statistics provided by the WordPress platform, the origin of the accesses was diverse, and they came not only from Brazil, but also from other countries, as demonstrated in - Table 3 .

We also noted that depending on the search term used in a known search engine like Google, the "Fissure and Hearing" blog link was made available as one of the first results, as shown in - Fig. 2, with the term cleft types and the term Eustachian tube.

Regarding the evaluation made by the professionals via the Emory questionnaire, we found that for the majority of the questions, the percentages obtained were $\geq 90 \%$, characterizing the quality of the blog as excellent, as shown in - Table 4.

Regarding the analysis of scales, we observed that despite the excellent score, the scales with lower scores corresponded to navigation (92\%) and structure (90\%), as can be seen in - Fig. 3 .

The evaluation of the blog is as important as the update, which will be performed annually through further reviews of the scientific literature. 

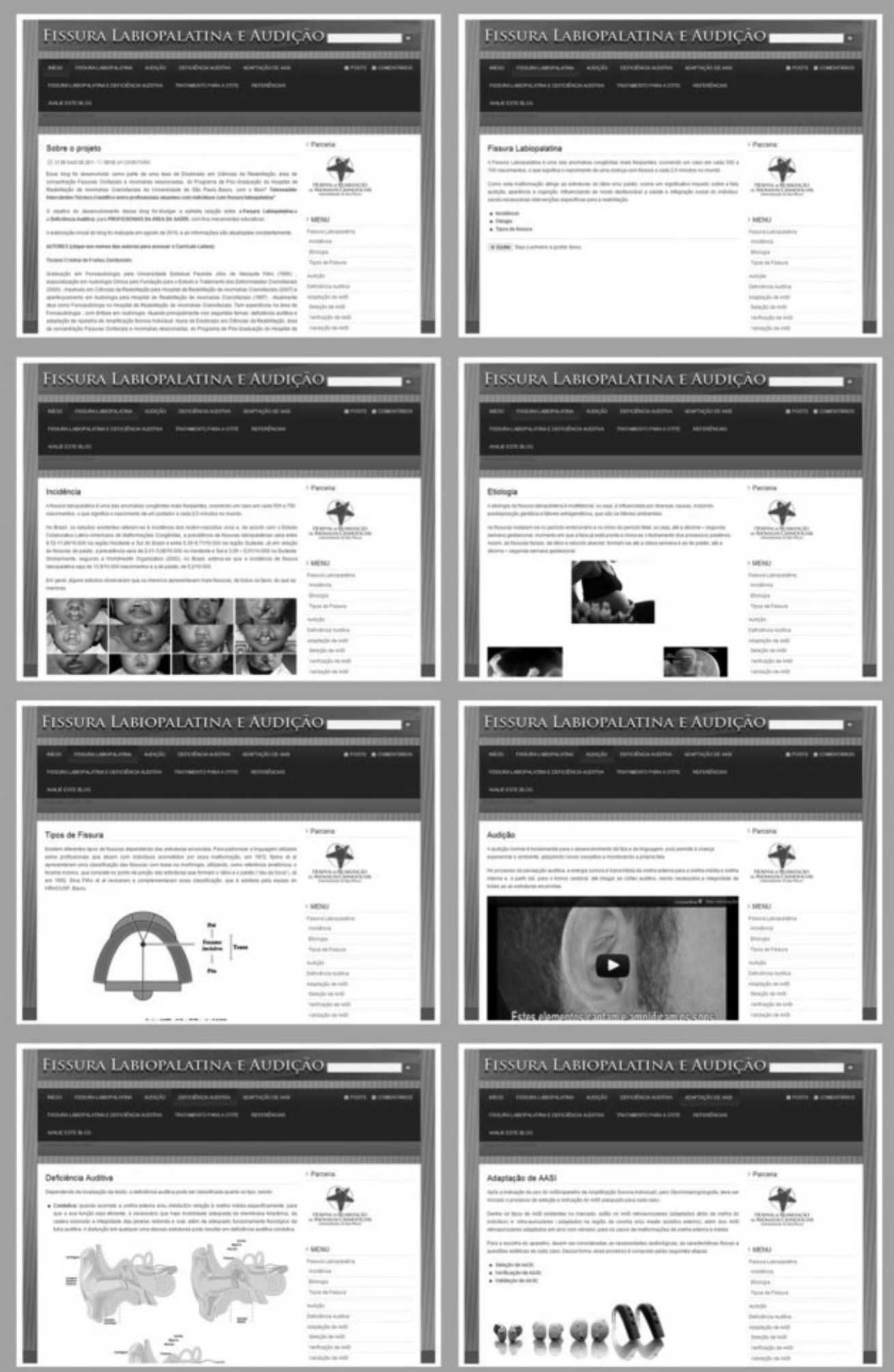

Fig. 1 Blog Fissura Labiopalatina e Audição (Cleft Lip and Palate and Hearing) internal pages with hypertext, images and videos.

\section{Discussion}

We chose to use the blog because of the absence of detailed knowledge or specific programming languages such as HTML, as well as because of the possibility of instant publications, chronological archiving of information, dissemination of texts, images, videos, insertion of hyperlinks and interactivity.

The division of the content into topics ( - Table 1 and - Fig. 1) coupled with optimization systems enabled the knowledge to become broader and more dynamic, and its use 
64 Blog about Cleft Lip and Cleft Palate and Hearing Maximino et al.

Table 3 Number of views obtained in each country from August 2010 to October 2015

\begin{tabular}{|l|l|}
\hline Country & Views in each country \\
\hline Brazil & 50,407 \\
\hline Portugal & 1,420 \\
\hline Germany & 1,376 \\
\hline United States & 1,242 \\
\hline Chile & 180 \\
\hline Switzerland & 143 \\
\hline Sweden & 134 \\
\hline Italy & 128 \\
\hline Bolivia & 121 \\
\hline Holland & 118 \\
\hline Mozambique & 106 \\
\hline Mexico & 105 \\
\hline Denmark & 101 \\
\hline Indonesia & 98 \\
\hline Finland & 82 \\
\hline Austria & 80 \\
\hline Angola & 79 \\
\hline United Kingdom & 78 \\
\hline Peru & 72 \\
\hline Spain & 72 \\
\hline Norway & 67 \\
\hline Belgium & 60 \\
\hline TOTAL & 56,269 \\
\hline & \\
\hline & 106 \\
\hline
\end{tabular}

has fostered a versatile support for the completion of the training for professionals ${ }^{27}$ in themes for the promotion of health, ${ }^{28}$ in addition to interactivity to express support for the understanding and applicability of the knowledge addressed. ${ }^{29}$

Careful selection of the blog's illustrations and links (-Fig. 1), with specific and coherent language for the selected target audience, is justified by the objective of this tool, which is used by more people and can effectively convey the information through features with different stimuli, assisting in the understanding of the content. ${ }^{30}$ In the health sector, the use of blogs can expedite and facilitate communication among experts, and serve as an additional educational resource and/or as supplementary education for professionals. ${ }^{28,29,31,32}$

During the analyzed period, there were a lot of visits to the "Fissure and Hearing" blog: 56,269 (-Table 3). The increasing use of the internet to obtain information in the health area by professionals, students, patients and the general population was also observed in other studies. ${ }^{17,18,31}$ The widespread access to ICTs is related to a greater proximity between the organizers and the target audience. ${ }^{30}$ The most outstanding motivational aspects were the ease of use, the fact that it was entertaining, the possibility to disseminate information, and the identification with the subject and the audience. $^{33}$

There was a high number of views outside of Brazil, in countries such as Portugal, Germany, the United States, Chile, among others (-Table 3 ), giving the blog the universal character of the internet described in the literature, ${ }^{34}$ with the dissemination of knowledge from the major centers to professionals of more remote areas or with reduced time availability, leading to the improvement of the professional practice. $^{35}$

One of the potential ways of coming across the blog is by doing a Google search; the blog appears among the first results, as shown in -Fig. 2 . This demonstrates the high interest of web users in the theoretical content of the blog: cleft lip and cleft palate and hearing.

The analysis of the quality of the blog through a questionnaire answered by professionals was justified by the search for an effective evaluation for the instrument to be widely used. 20

As a result of the evaluation by the participants, the quality was characterized by 67 evaluators (89\%) as excellent. ${ }^{21,22}$ Thus, the blog can be considered an excellent source of health information; the interested public can access it and easily understand the available information, and its use can be recommended (-Table 4 and -Fig. 3 ).

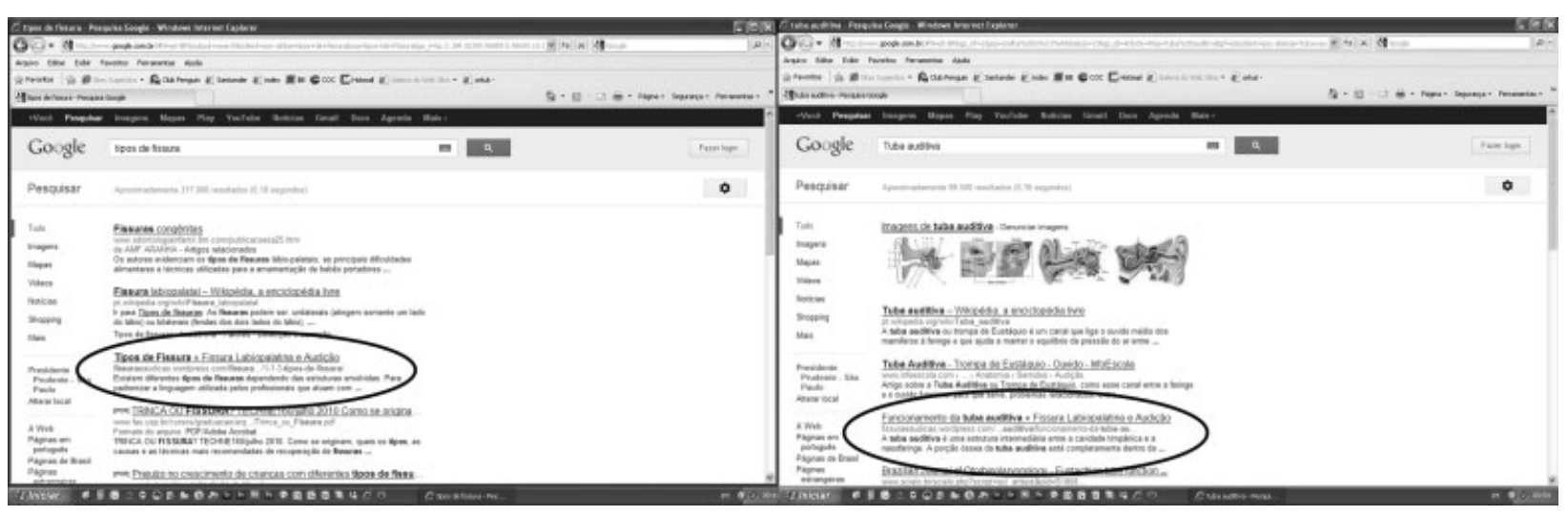

Fig. 2 Search tool in the "Fissure and Hearing" blog link. 
Table 4 Scores of the Emory questionnaire about the quality of the blog, according to the proposed score

\begin{tabular}{|c|c|c|c|}
\hline Questions & EMORY & Questions & EMORY \\
\hline Q1 - clear purpose & $99 \%$ & Q19 - internal links provided easy navigation & $98.6 \%$ \\
\hline $\begin{array}{l}\text { Q2-information that does not } \\
\text { seem to be advertising }\end{array}$ & $98.6 \%$ & Q20 - retrieval of information in a timely manner & $98.5 \%$ \\
\hline Q3 - unbiased information & $99.3 \%$ & Q21 - needs to offer search engine & $80.7 \%$ \\
\hline Q4 - range of views & $98.4 \%$ & Q22 - offers search engine & $89.8 \%$ \\
\hline Q5 - covers all aspects of the matter & $95.2 \%$ & Q23 - blog organization & $98.6 \%$ \\
\hline Q6 - provides external links & $96.5 \%$ & Q24 - link to download any necessary software & $88.4 \%$ \\
\hline Q7 - correct information & $98.4 \%$ & Q25 - relevant external links & $100 \%$ \\
\hline Q8 - documented sources & $98.6 \%$ & Q26 - operable external links & $100 \%$ \\
\hline $\begin{array}{l}\text { Q9 - states that complies with the } \\
\text { principles of the HON code }\end{array}$ & $96.6 \%$ & Q27 - current external links & $100 \%$ \\
\hline Q10 - sponsorship/link to an institution & $93.3 \%$ & Q28 - appropriate external links & $99.3 \%$ \\
\hline $\begin{array}{l}\text { Q11 - information and credentials of } \\
\text { the indicated authors }\end{array}$ & $99.3 \%$ & Q29 - external links of reliable information & $99.3 \%$ \\
\hline Q12-provided contact & $93,9 \%$ & Q30-important external links & $98 \%$ \\
\hline Q13 - provided publication date & $95.2 \%$ & Q31 - graphs, pictures and blog art add value & $97.3 \%$ \\
\hline Q14 - date of last update & $94.3 \%$ & Q32 - charts/figures do not delay page loading & $97.2 \%$ \\
\hline Q15 - clear public target & $94 \%$ & Q33 - option to display text only & $82.5 \%$ \\
\hline $\begin{array}{l}\text { Q16 - level of detail of the } \\
\text { appropriate information }\end{array}$ & $98.6 \%$ & Q34 - use only the texts & $90.6 \%$ \\
\hline Q17 - appropriate reading level & $98 \%$ & Q35 - options for people with disabilities & $78.3 \%$ \\
\hline Q18 - suitable technical terms & $96.6 \%$ & Q36 - No audio/video, the information would be clear & $96.4 \%$ \\
\hline
\end{tabular}

Abbreviation: HON, health on the net.

Notes: Scores higher or equal to $90 \%=$ excellent quality; scores between $75 \%$ and $89 \%=$ adequate quality; scores lower than $75 \%=$ poor quality.

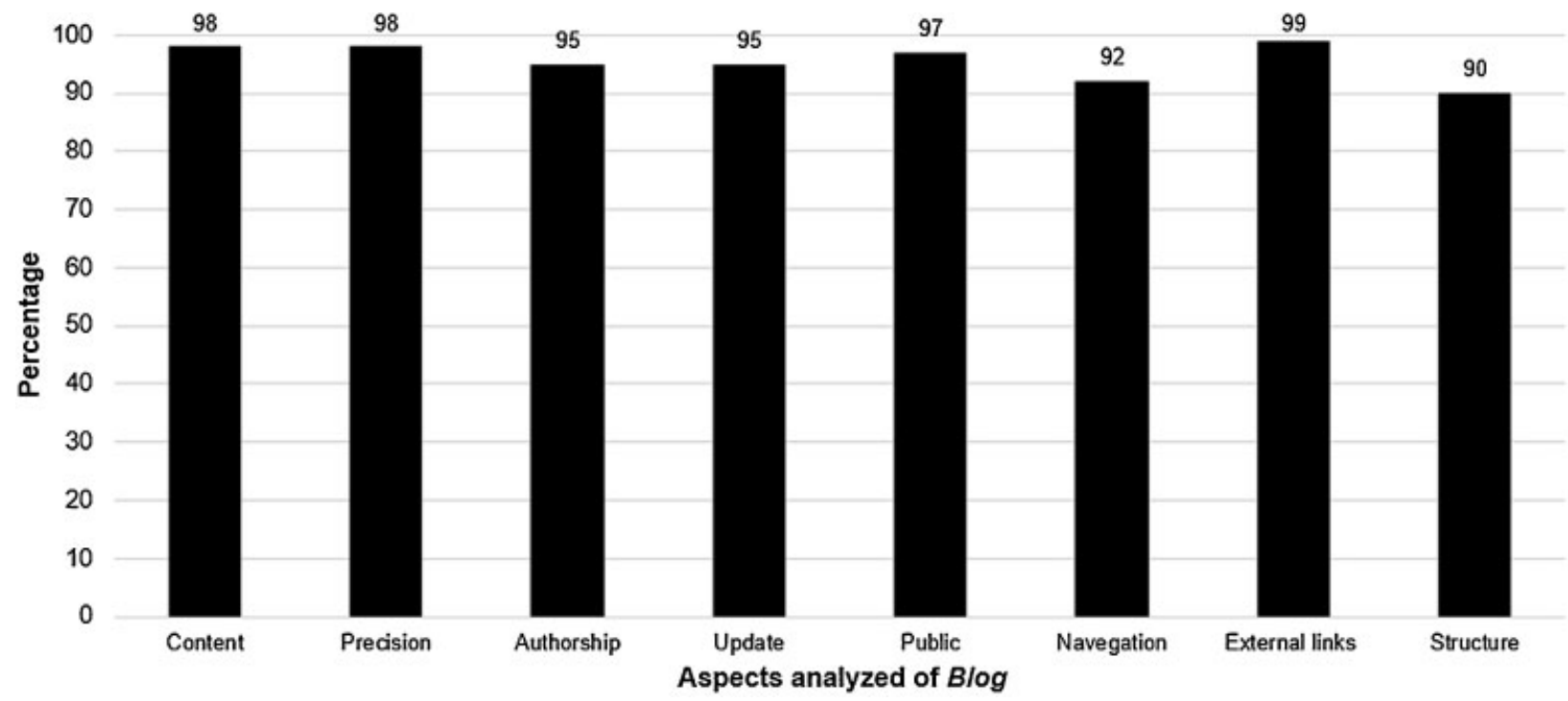

Fig. 3 Total score of the Emory questionnaire distributed by the scales of the aspects analyzed. 
It is noteworthy that for the preparation of the blog, including its contents, reliable references were used, as were the results of previous studies, ${ }^{36}$ in addition to considering the analyses of the professionals working in this area, as well as the use of reading facilitation strategies and use of the tool, making it simple, objective, concise and attractive.

\section{Conclusion}

The developed blog enables the dissemination of information about cleft lip and cleft palate and hearing through ICTs. Clearly, there is a need for further actions in this direction, covering a greater number of health professionals, based on the principles established in the literature on various issues for wider dissemination of high quality information, especially regarding tele-audiology.

\section{Conflicts of Interest}

Authors have no conflicts of interest to disclose.

\section{Source of Study}

Authors declare having received no financial support to conduct the study.

\section{References}

1 Mossey PA, Little J. Epidemiology of oral clefts: an international perspective. In: Wyszynski DF, editor. Cleft lip and palate from origin to treatment. New York: Oxford University Press; 2002: 127-158

2 World Health Organization. Global registry and database on craniofacial anomalies: report of WHO registry meeting on Craniofacial Anomalies. Geneva: World Health Organization; 2003 [cited 2012 Jun 21]. Available from: http://www.who.int/ genomics/anomalies/en/CFA-RegistryMeeting-2001.pdf

3 Santos EC, Leite SGS, Santos SMP, et al. Qualitative analysis of the dietary pattern of children with cleft lip and/or palate assisted at a hospital in Goiânia-GO. J Health Sci Inst 2011; 29(03):183-185

4 Leiva N, Corsini R, Nieto E. Adhesive bridge in a patient with cleft lip and palate: a temporary solution with esthetic commitment. Rev Clín Periodoncia Implantol Rehabil Oral 2013;6(01):33-37

5 Fernandes TFS, Mesquita ST, Feniman MR. The social impact on individuals with communication disorders associated with cleft lip and palate with and without hearing loss. Audiol Communic Res 2015;20(01):40-47

6 Palandi BBN, Guedes ZCF. Aspects of speech of subjects with cleft palate corrected in different ages. Rev CEFAC 2011;13(01): 8-16

7 Amaral MIR. Martins JE, Santos MFC. A study on the hearing of children with non-syndromic cleft palate/lip. Rev Bras Otorrinolaringol (Engl Ed) 2010;76(02):164-171

8 Lemos ICC, Feniman MR. Sustained Auditory Attention Ability Test (SAAAT) in seven-year-old children with cleft lip and palate. Rev Bras Otorrinolaringol (Engl Ed) 2010;76(02):199-205

9 Feniman MR, Souza TC, Teixeira TS, et al. Perception of parents about the auditory attention skills of his kid with cleft lip and palate: retrospective study. Arq Int Otorrinolaringol 2012;16(01): 115-120
10 Moraes TFD, Salvador KK, Cruz MS, et al. Hearing process in children with cleft lip and palate with or without history of otitis. Arq Int Otorrinolaringol 2011;15(04):431-436

11 Flynn T, Möller C, Jönsson R, Lohmander A. The high prevalence of otitis media with effusion in children with cleft lip and palate as compared to children without clefts. Int J Pediatr Otorhinolaryngol 2009;73(10):1441-1446

12 Kwan WM, Abdullah VJ, Liu K, van Hasselt CA, Tong MC. Otitis media with effusion and hearing loss in Chinese children with cleft lip and palate. Cleft Palate Craniofac J 2011;48(06): 684-689

13 Piazentin-Penna SHA, Jorge JC. Avaliação e tratamento dos distúrbios de audição. In: Trindade IEK, Silva Filho OG, editors. Fissuras Labiopalatinas: uma abordagem interdisciplinar. São Paulo: Livraria Santos; 2007:165-172

14 Luthra S, Singh S, Nagarkar AN, Mahajan JK. The role of audiological diagnostics in children with cleft lip \& palate (CLP). Int J Pediatr Otorhinolaryngol 2009;73(10):1365-1367

15 Haney M, Silvestri S, Van Dillen C, Ralls G, Cohen E, Papa L. A comparison of tele-education versus conventional lectures in wound care knowledge and skill acquisition. J Telemed Telecare 2012;18(02):79-81

16 Nilsen LL, Moen A. Teleconsultation - collaborative work and opportunities for learning across organizational boundaries. J Telemed Telecare 2008;14(07):377-380

17 Shivute MI, Maumbe BM, Owei VT. The use of information and communications technology for health service delivery in Namibia: perspectives of the health service providers. J Telemed Telecare 2008;14(06):285-289

18 Bonnardot L, Rainis R. Store-and-forward telemedicine for doctors working in remote areas. J Telemed Telecare 2009;15(01):1-6

19 Kreps GL, Neuhauser L. New directions in eHealth communication: opportunities and challenges. Patient Educ Couns 2010; 78(03):329-336

20 Breckons M, Jones R, Morris J, Richardson J. What do evaluation instruments tell us about the quality of complementary medicine information on the internet? J Med Internet Res 2008;10(01):e3http://www.jmir.org/2008/1/e3/ [access July 27, 2016] [Internet]

21 Emory - University Rollins School of Public Health. Health-Related Web Site Evaluation Form [Internet]. 1998 [access jul 27, 2016]. Available from: http://www.sph.emory.edu/WELLNESS/instrument.html

22 Bastos BG. Telessaúde: avaliação de um website como ferramenta de auxílio ao aconselhamento de pais de crianças usuárias de aparelho de amplificação sonora individual [dissertation]. Bauru: Faculdade de Odontologia de Bauru, Universidade de São Paulo; 2011

23 Molini-Avejonas DR, Rondon-Melo S, Amato CA, Samelli AG. A systematic review of the use of telehealth in speech, language and hearing sciences. J Telemed Telecare 2015;21(07):367-376

24 Corrêa CdeC, Freire T, Zabeu JS, et al. Teleducation about Cleft Lip and Palate: An Interdisciplinary Approach in the Promotion of Health. Int Arch Otorhinolaryngol 2015;19(02):106-111

25 Filatro A, Piconez SCB. Design instrucional contextualizado: planejamento, elaboração e avaliação de materiais didáticos para educação à distância [Internet]. 2004. [access jul 27, 2016]. Available: http://www.abed.org.br/congresso2004/por/pdf/049TC-B2.pdf

26 Rosenfeld L, Morville P. Information Architecture for the World Wide Web. 2ed. Sebastopol: O'Reilly; 2002

27 Pulga MJ, Spinardi-Panes AC, Lopes-Herrera SA, Maximino LP. Evaluating a speech-language pathology technology. Telemed J E Health 2014;20(03):269-271

28 Germani ACCG, Oliveira AAP, Chiesa AM, et al. Evaluation of educational technologies to human resources formation about health promotion in an interprofessional experience. J Bras Telessaúde 2014;3(01):200-210 
29 Leggatt-Cook C, Chamberlain K. Blogging for weight loss: personal accountability, writing selves, and the weight-loss blogosphere. Sociol Health Illn 2012;34(07):963-977

30 Whitten P, Holtz B, Cornacchione J, Wirth C. An evaluation of telehealth websites for design, literacy, information and content. J Telemed Telecare 2011;17(01):31-35

31 Gonçalves FG. Blog - o que é? Como funciona? E por que "blogar"?. Radiol Bras 2011;44;03:7-8

32 Maia F, Struchiner M. The use of weblogs and orkut communities as pedagogical tools in courses in the health area. Interface Comunic Saude Educ 2010;14:905-918
33 Hsu CL, Lin JCC. Acceptance of blog usage: The roles of technology acceptance, social influence and knowledge sharing motivation. Inf Manage 2008;45(1):65-74

34 World Health Organization. Telemedicine. [cited 2012 jun 21]. Available from: http://www.who.int/goe/publications/goe_atlas_2010. pdf

35 Blasca WQ, Kuchar J, Pardo-Fanton CS, et al. A pattern of hearing health education. Rev CEFAC 2014;16(01):23-30

36 Zambonato TCF, Feniman MR, Blasca WQ et al. Perfil de usuários de AASI com fissura labiopalatina. Rev Bras Otorrinolaringol (Engl Ed) $2009 ; 75(06): 888-892$ 